УДК 9

DOI $10.21661 / \mathrm{r}-115991$

\title{
Т.Г. Кривцова
}

\section{ИСТОРИЯ СОЗДАНИЯ СТАВРОПОЛЬСКОГО МУЗЕЯ НАГЛЯДНЫХ ПОСОБИЙ}

Аннотация: в статье представлены материалы, связанные с созданием и деятельностью музея наглядных пособий им. Г.К. Праве. Автором отмечается, что музей был создан в начале ХХ века и пережил такие серьезные потрясения, как револючия, война и процесс объединения.

Ключевые слова: музей, Ставрополь, Северньй Кавказ, коллекции, собрания, предметьл.

\section{T.G. Krivcova \\ THE HISTORY OF STAVROPOL MUSEUM VISUAL AIDS DEVELOPMENT}

Abstract: the article describes the materials, representing the G.K. Prave museum visual aids development and activity. The author points out, that the museum was established in the beginning of the XX century and experienced such events as revolution, war and the process of reunion.

Keywords: museum, Stavropol, North Caucasus, collections, compendiums, subjects.

Во все времена музеи считались учреждениями, которое занимались хранением, и изучением исторически и культурно значимых предметов, отражающих профиль коллекций и экспозиции самих музеев. За последнее столетие изменилось понимание этих учреждений. Однако фундаментальное значение музея, которое состоит в сохранение главных достижений и ценностей прошлого не изменилось. Отсюда вполне интересно обращение к истории создания музеев не только губернского, но и городского уровня. 
16 декабря 1904 года в городское управление г. Ставрополя обратился общественный деятель, нотариус, а также гласный городской думы Георгий Константинович Праве (1862-1925) с просьбой принять в собственность города разнообразные естественнонаучные коллекции и довольно богатую научную библиотеку для основания городского подвижного музея учебных пособий. Дар был прият 3 декабря 1904 года, кроме того, были ассигнованные средства на его содержания в размере 500 рублей. Г.К. Праве сам определяет свое книжное собрание как научную библиотеку. В ее основу была положена частная коллекция, состоящая из двух тысяч книг, по разным отраслям науки. Самую многочисленную составили естественнонаучные произведения [1, с. 2]. Музей получил название Городского музея Учебных Пособий и должен был стать чисто школьным музеем, представляющим из себя собрание наглядных пособий. Такое довольно узкое понимание задач никогда не разделялось его основателем, сам Г.К. Праве считал, что музей должен был стать научно-исследовательским учреждением. Кроме того, по его мнению, он должен был вести просветительскую работу в широких слоях городского населения. С 1906 г. музей получил официальный статус. Благодаря старанием Георгия Константиновича Праве, музей к началу Первой мировой войны располагал уникальными коллекциями по учебным предметам, сельскому хозяйству, множество гербария, этнографические и другие коллекции.

Создание музея и комплектования коллекций в его фондах, потребовали от Г.К. Праве огромных сил, материальных затрат, в том числе и личных. Георгий Константинович сумел привлечь к работе довольно много помощников, в том числе из местной интеллигенции. К тем людям, которые не остались в стороне и помогли начинающему тогда музею относится, зоолог Н.Я. Динник, который внес огромный вклад в изучения млекопитающих животных на Северном Кавказе. Кроме того, Николай Яковлевич прекрасно разбирался в полевой зоологии, о чем говорит значительно количество работ, посвящённая наблюдению 
за животными в их естественной среде обитания. Он интересовался систематикой таких животных, как рыси, медведи, кабаны, именно Н.Я. Динник первым описал предкавказскую косулю [2, с. 18].

Еще одним человеком, который помогал Г.К. Праве в его музейной деятельности был ботаник А.П. Норман, значительный вклад в развитие музея внесли такие ученые как энтомолог В.Н. Лучник, историк и археолог Г.Н. Прозрителев. Нельзя не упоминать и семью Г.К. Праве, которая всячески поддерживала все его начиная. Жена Г.К. Праве, сын и четыре дочери работали сотрудниками музея на добровольных началах, то есть бесплатно [1, с. 2].

Первоначально музей имел довольно скромные объемы, так что по решению местных властей, для него было отведено всего две комнаты в двухэтажном здании на улице Гимназической (сегодня это улица Морозова) при бесплатной библиотеке. Однако его собрание довольно быстро расширялось, поэтому был принято решение о перенесении музея в 1908 году другое здание при гимназиях [3, с. 40]. В 1911 году Г.К. Праве отправляется путешествовать по странам Европы. Он побывал в Германии, Чехии. Соответственно бывая в разного профиля музеях странах Европы Георгий Константинович знакомится с особенностями экспозиционной деятельности, приобретает бесценный опыт по комплектованию фондов, проникается идеями, которые к тому времени охвачены все западные музеи, одна из которых состоит в привязанностях к естественной истории. Исходя из того представления, человек, согласно науке начала XX века прежде всего зоологическая единица. Именно на средства выделенные местными властями Г.К. Праве приобретает в Европе коллекции по многим разделам естественной истории [3, с. 40].

В 1912 году под музей было выделено новое здание на Александровской площади. В этом здании располагались торговые ряды, а музею было отведено крыло на втором этаже. Еще одним событием городского значения стало открытие в 1914 году постоянной экспозиции приборов, макетов, разнообразных таблиц по физии, зоологии, химии, географии [1, с. 2]. Кроме того, экспозицию обо- 
гатила коллекция минералов, разнообразный гербарий собранный ботаником А.П. Норманом, представленный тысячами видов растений. Судя, по статистическим данным в год открытия экспозиции музей посетили около 54 тысяч человек. В сравнении даже с современностью это довольно большая цифра. На том момент времени это был настоящий успех, который в свою очередь говорит о большом интересе у населения к музею. Такой интерес был вызван и выгодным расположением здания. Оно располагалось в центральной части базарной площади, где собиралось большое количество населения губернии.

В том же 1914 году фондохранилище музея пополнились дольно ценными образцами старинного огнестрельного и холодного оружия. Вся эта коллекция поступила из военно-исторического музея 83-го Самурского пехотного полка, который ушел из Ставрополя на германский фронт [1, с. 2].

В годы Первой мировой войны Г.К. праве пытался бороться с повышением цен, выступал как нотариус с предложением введение «сухого закона», который был поддержан в городской думе и введен осенью 1914 года. В 1916 году Ставропольская Городская дума присоединилась к протоколу Губернского земского собрания о преобразовании Ставропольского городского музея в Земско-городской музей им М.В. Праве, которая являлась женой Г.К. Праве [1, с. 2]. По его инициативе музею было присвоено ее имя. Нужно отметить, что по законам того времени присвоение имени музею или просто какой-либо организации являлось частным делом и местными властями официально никак не фиксировалось.

Жизнь в революционное время, для музеев тоже было непростым испытанием, учитывая, то факт, что везде по стране к ним стали относится не очень хорошо. Тем не менее, в 1918 году музею имени М.В. Праве было выдана охранная грамота командованием Таманской армии [3, с. 42]. Музей в это непростое время работал, хотя посетителей в нем стало заметно меньше. В основном в музей ходили военные люди. Фонды музея так же пополнялись бойцами Красной армии, отдавалось все то, что было изъято у зажиточной прослойки. Именно в это время в 1920 году в музеи был открыт художественный отдел. В экспозиции были представлена, разнообразная антикварная мебель, картины и скульптуры 
известных мастеров, которые были изъяты у купцов и зажиточных граждан. Позже появились и полотна, которые были привезены из Эрмитажа, который по мнению новой власти должен был делиться с местными музеями.

Пополнялись коллекции музея самыми разнообразными путями. Так еще 1890 году, коллекции, собранные в Ставрополе, были направлены в Тифлис, где впоследствии был организован Кавказский музей. Затем был создан еще один музей в Тифлисе, который получил названия «Храм Славы». Позже, а именно в 1914 году коллекции этого музея были эвакуированные в Ставрополь [1, с. 2]. Это решение было принято в связи с открытием турецкого фронта. Про коллекции забыли в связи с революционными событиями, а затем нашли их в особняке Венецианова, который располагался по Николаевскому проспекту. Об этом узнал Г.К. Праве и отправился туда, то, что он увидел там, потрясло музейщика. Коллекции находились в плохом состоянии, часть была разграблена, предметы хранились в сыром помещении в ящиках. Г.К. Праве добился того, что вечером того же дня все предметы были переданы в музей, для транспортировки было выделено 2250 рублей [3, с. 43].

С весны 1920 по 1924 год музей стал именоваться Ставропольским губернским центральным народным музеем им. М.В.Праве $[1$, с. 2]. В эти годы В.Г. Гниловской, будучи еще подростком, знакомится с Г.К. Праве. Именно это знакомство и определило то, чем, занимался потом В.Г. Гниловской, который стал выдающимся ученым, краеведом Северного Кавказа.

Несмотря на то, что музей был расширен в годы Гражданской войны, тем не менее, положение его было не из легких. Учреждение снимаю с бюджетного финансирования, уменьшают зарплату. Именно в эти тяжелые годы Г.К. Праве, было нелегко справится со всем эти, поэтому он пишет свой «Меморандум», который адресует местным властям. В нем Георгий Константинович делает попытку объяснить, что такое музей, какие цели преследует и что хочет донести. Уже в это время идут разговоры о слиянии двух музеев- М.В. Праве и музея Северного Кавказа основанным Г.Н. Прозрителевым. 
С 1924 года по 1930 музей стал называться Ставропольским Центральным народным. 25 августа 1925 года умирает Г.К. Праве. После его смерти директором музея становится талантливый ученый, энтомолог, друг Г.К. Праве - Виктор Николаевич Лучник.

В 1925 году в городе создается специальная комиссия, которая занимается вопросами объединения двух музеев. Здание, где располагался музей Северного Кавказа, было решено отдать под квартиры. В 1927 экспонаты музея, без согласия с Г.Н. Прозрителевым были перевезены в здание городского музея. Это решение обосновывалось тем, что в музее Праве были свободные площади для хранения коллекций. Само по себе объединение музей, по мнению городских властей не должно было проходить в спешке. Однако, на практике, такого не произошло. Музеи были объединены, а сами коллекции двух этих музеев, хранятся и по ныне в фондах Ставропольского государственного историко-культурного и природно-ландшафтного музея-заповедника им. Г.Н. Прозрителева и Г.К. Праве.

\section{Сиисок литературы}

1. СГМЗ.Ф. - №2. Опись. - №2. - С. 2-3.

2. Хе В.Х. Николай Яковлевич Динник - основоположник идей рационального природопользования, экологии и охраны млекопитающих Кавказа // Современные проблемы науки и образования (Биологические науки) / Ставропольский государственный университет. - 2008. - №6. - С. 18.

3. Ставропольский государственный краеведческий музей им. Г.Н. Прозрителева и Г.К. Праве: Роман о музее. - Ставрополь, 2005. - С. 40-43.

Кривцова Татьяна Геннадьевна - младший научный сотрудник ГБУК СК «Ставропольский государственный историко-культурный и природно-ландшафтный музей-заповедник им. Г.Н. Прозрителева и Г.К. Праве», Россия, Ставрополь. 
Krivcova Tatyana Gennadevna - junior research fellow of Stavropol Territory State Budgetary Institution of Culture "G.N. Prozritelev and G.K. Prave Stavropol State Historical-Cultural Nature and Landscape Museum-Preserve", Russia, Stavropol. 